\title{
European patent directive in critical test over genes
}

London. Six years of effort by the European Commission (EC) in Brussels to harmonize legislation on biotechnology patents in the member states of the European Union (EU) are in the balance. At issue is the continuing disagreement between industrialists and environmentalist groups over whether parts of the human body - including genes and human cell lines - can be patented.

A 'conciliation committee' will meet in Brussels next week in an attempt to bridge the gap that still exists between the Council of Ministers, representing the 12 member states of the EU, which supports such patents, and the European Parliament, which voted in May to oppose them.

The subject of the meeting is a draft directive, drawn up by EC officials but extensively revised in the light of comments from the parliament, which seeks to establish common rules on biotechnology patenting for the member states and to clarify the boundary between what can and cannot be patented (see Nature 361, 285; 1993).

The biotechnology industry, which originally supported attempts at harmonization, has already accepted some of the conditions demanded by the parliament. For example, it

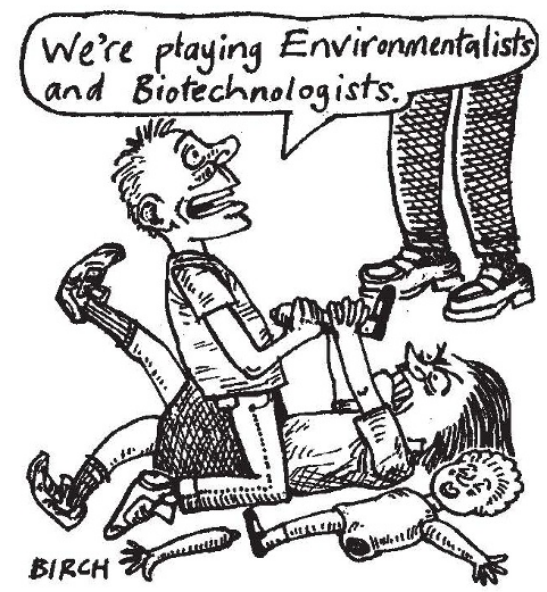

has agreed to a condition, inserted after pressure from farming groups, that farmers should be exempt from standard licensing requirements on genetically engineered seeds when producing their own seeds to grow from one season to the next.

But the industry, and in particular various large pharmaceutical companies, remains firm in its conviction that it must be free to patent genes and human cells where these have been isolated and characterized outside the human body. This is necessary, it says, to allow it to profit from new diagnostic and therapeutic treatments.

Interpharma, for example, the association that represents the powerful Swiss phar- maceutical industry, has issued a statement in which it confirms its support for patents on genes and gene fragments "in a form that does not occur in nature". The statement adds: "For example, isolated genes do not occur naturally, nor do large quantities of purified proteins; they should, therefore, be patentable."

This position is directly contested by the European Green Party, which has accused the biotechnology industry of "diminishing humanity in its breathless pursuit of profits", and is asking the European Parliament either to throw out the directive or to insist on its amendment, approved in a vote in May, forbidding the patenting of isolated human body parts.

"What we are talking about here is the commercialization of the human body," Hiltrud Breyer, a member of the European Parliament who represents the German Green party, told a press conference which was held in Brussels earlier this month. "If this directive is adopted [without the amendment], then we will have privatized humanity in the European Union."

While the Green party, as well as supporters from other parliamentary groups, intend to use case histories to back their arguments against patents, representatives of the biotechnology industry claim that the principle of being able to patent genes and human cell lines is so important that they would be prepared to see the whole directive abandoned rather than give way on the issue.

Others point out that, in a series of recent decisions, the European Patent Office (EPO) has demonstrated that it is prepared, in general, to accept the industry's definition of what should and should not be patented under the terms of the European Patent Convention.

If the conciliation committee rejects the parliament's amendment, its decision could, under the terms of the Maastricht Treaty, still be rejected by an absolute majority (that is a majority vote of all members) in the parliament.

Environmentalist representatives such as Sue Mayer of Britain's Greenpeace claim that there would be widespread public support for such action. Accepting the directive without the parliament's amendment, she says, would be seen as giving parliamentary approval to the patenting of genes and other human parts.

But the biotechnology industry is reluctant to submit itself to this particular test of public acceptability. No one will therefore be surprised if this particular effort at harmonizing European patent legislation ends up being quietly shelved. David Dickson

\section{Taiwan's 'NIH' begins to bear its first fruit}

Taipei, Taiwan. Despite initial suspicions and a lack of legal status, Taiwan's emerging National Health Research Institutes (NHRI), modelled on both the US National Institutes of Health and Britain's Medical Research Council, is already making its mark on medical research.

Officially the NHRI, which aims to have about 500 researchers in its intramural programme within five years, does not yet exist. A new law setting up the institutes has only just passed the first of three stages in the Legislative Yuan. But with strong support from the medical community, it is widely expected to reach the statute books by the end of this year or early 1995.

Furthermore, construction has only just begun of a building that will provide the NHRI with temporary headquarters. These will take up several floors of the new Institute of Biomedical Sciences of Academia Sinica in Nakang, Taipei, before moving to a new site in Taipei in about five years.

But scientists are already lining up to join the intramural programme expected to start next year. And NHRI is having an impact on medical research in Taiwan through its extramural grant programme which began three years ago (see Nature 366, 500; 1993). This provides grants of up to NT $\$ 15$ million (US\$0.6 million) a year to 39 centres of excellence in universities and hospitals, as well as 25 grants of up to NT\$5 million for individual researchers throughout Taiwan.

Cheng-Wen $\mathrm{Wu}$, the director of the Institute of Biomedical Sciences who is leading the efforts to create the NHRI, says that most of the grant-holders got "really good" reviews in its first external review a few months ago. A further 20 new grants will be added to the programme this year and many existing grants will be extended.

$\mathrm{Wu}$ admits that some people were initially "suspicious" of his plans to establish the NHRI. His own institute has grown rapidly to become the largest of Academia Sinica's 21 institutes. Some directors of other institutes are not only jealous of its size, but also sceptical about its output, particularly as the Taiwanese government is restricting research spending because of large outlays for defence.

But $\mathrm{Wu}$ claims that he now has the full backing of Taiwan's medical community. The deans of all university medical schools, the heads of research hospitals and Taiwan's medical association and pharmaceutical association are all supporting the legislation to establish NHRI.

$\mathrm{Wu}$ expects the intramural programme to get under way in the new building next spring.
David Swinbanks 